\title{
X-Linked Adrenal Hypoplasia Congenita
}

National Cancer Institute

\section{Source}

National Cancer Institute. X-Linked Adrenal Hypoplasia Congenita. NCI Thesaurus. Code C123725.

A X-linked condition characterized by underdevelopment of the adrenal gland and adrenal insufficiency caused by mutation(s) in the NROB1 gene, resulting in decreased activity of the nuclear receptor protein DAX1, which may be associated with hypogonadotropic hypogonadism. 